THE DEAD OF THE IRISH REVOLUTION 


\section{THE DEAD}

\section{OF THE IRISH}

REVOLUTION

Eunan O’Halpin and Daithí Ó Corráin 
Copyright @ 2020 Eunan O’Halpin and Daithí Ó Corráin

Introduction (๑) 2020 Eunan O’Halpin

Original charts by Peter Connell

All rights reserved. This book may not be reproduced in whole or in part, in any form (beyond that copying permitted by Sections 107 and 108 of the U.S. Copyright Law and except by reviewers for the public press) without written permission from the publishers.

For information about this and other Yale University Press publications, please contact:

U.S. Office: sales.press@yale.edu yalebooks.com

Europe Office: sales@yaleup.co.uk yalebooks.co.uk

Set in Minion Pro by IDSUK (DataConnection) Ltd

Printed in Great Britain by TJ International Ltd, Padstow, Cornwall

Library of Congress Control Number: 2020943257

ISBN 978-0-300-12382-1

A catalogue record for this book is available from the British Library.

1098876544321 
EO'H

In memory of

Keith Jeffery (1952-2016)

DÓC

In memory of

Donnchadh Ó Corráin (1942-2017)

Clare Frances Murphy (1947-2018) 
